\title{
COMMENTS
}

\section{Cameras in Teddy Bears: Electronic Visual Surveillance and the Fourth Amendment}

\author{
Kent Greenfield $\dagger$
}

Distinguished judicial figures from Justice Brandeis to Judge Posner have recognized that electronic surveillance poses a serious threat to the American public's constitutional interest in being "secure in their persons, houses, papers, and effects." In 1928, Justice Brandeis expressed alarm that the unregulated use of technology enabling the government to wiretap a telephone endangered the public's "right to be let alone - the most comprehensive of rights and the right most valued" by "civilized" people. ${ }^{2}$ He warned that "[a]s a means of espionage, writs of assistance and general warrants are but puny instruments of tyranny and oppression when compared with wire tapping." Judge Posner, in a 1984 Seventh Circuit opinion, declared that "television surveillance is exceedingly intrusive, ... and inherently indiscriminate, and ... could be grossly abused-to eliminate personal privacy as understood in modern Western nations."

The surveillance that was the object of Judge Posner's warning, electronic visual surveillance ("EVS"), is the type of government investigation that is perhaps the most dangerous to personal

$\dagger$ A.B. 1984, Brown University; J.D. Candidate 1992, The University of Chicago.

' US Const, Amend IV. The Amendment reads in full:

The right of the people to be secure in their persons, houses, papers, and effects, against unreasonable searches and seizures, shall not be violated, and no Warrants shall issue, but upon probable cause, supported by Oath or affirmation, and particularly describing the place to be searched, and the persons or things to be seized.

2 Olmstead $v$ United States, 277 US 438, 478 (1928) (Brandeis dissenting), overruled by Berger $v$ New York, 388 US 41 (1967).

${ }^{3}$ Olmstead, 277 US at 475 (Brandeis dissenting).

- United States v Torres, 751 F2d 875, 882 (7th Cir 1984). Many other judges and justices have expressed similar concerns about the possible dangers of surveillance technology. See Note, Electronic Visual Surveillance and the Fourth Amendment: The Arrival of Big Brother?, 3 Hastings Const L Q 261, 263-64 (1976). 
privacy. Notwithstanding this danger, EVS is not subject to any federal statutory controls, while less intrusive technologies like audio bugs and wiretaps are governed by tight statutory restrictions. Courts hold law enforcement officials performing EVS to the standards of the Fourth Amendment, but refuse to apply the strict standards that govern audio surveillance. This creates an anomaly in the law. The more intrusive surveillance technology of EVS is subject to fewer restrictions than less dangerous technologies.

This Comment explores the Fourth Amendment requirements for government use of EVS, and suggests a solution to this anomaly. Section I surveys the EVS technology available to the government. Section II reviews the framework of the Supreme Court's Fourth Amendment jurisprudence relevant to surveillance issues in general, discussing the parameters of both the warrant requirement and the reasonableness inquiry. Section III looks at how the lower courts have applied Fourth Amendment analysis to EVS in particular. The analysis in Section IV offers a new perspective on the Fourth Amendment requirements in the context of EVS. It argues that most of these lower courts have misapplied Fourth Amendment law, permitting EVS that fails both the warrant requirements and the reasonableness standard of the Fourth Amendment.

In the course of the analysis, this Comment proposes new standards for EVS that will both enable law enforcement officials to use this technology to fight crime and also protect the American people from violations of their Fourth Amendment rights. These standards could shape law enforcement officials' use of EVS and guide judges when deciding whether to authorize EVS warrants and when judging their sufficiency.

\section{The Technology Available and the Risk to Privacy}

Before electronic surveillance technology was available, individuals themselves could protect their right to be secure. They could lock their doors, close their curtains, conceal their belongings, and mute their voices. In the event of a government search, their privacy would certainly be infringed, but the scope of the search was limited by its nature, since only physical items could be the focus. After the search ended, the privacy of activity and conversation was restored. With the development of bugging and wiretapping technology, people became less able to protect themselves, 
and the nature of the search was less self-limiting. ${ }^{5}$ Nevertheless, people who feared they were the objects of audio surveillance could mute or mask their conversations, move their conversations elsewhere, or communicate in other, non-verbal, ways. Fear of such surveillance thus had only a limited chilling effect on the way individuals lived their lives. Fourth Amendment and statutory protections of privacy and security were clarified and strengthened to account for this increase in intrusion, ${ }^{6}$ but people were also able to protect themselves.

With the development of EVS technology, however, the government's ability to infringe on privacy increased significantly. EVS is one of the most intimidating weapons in a modern police officer's arsenal because it can substitute for the eyes of law enforcement officials in places where it would be impossible for them to be physically present. ${ }^{7}$ The nature of EVS allows privacy to be infringed absolutely.

The government has several types of EVS technology at its disposal, each with its own unique capabilities. Miniature video cameras readily available on the retail market weigh less than two pounds and can fit in the palm of one's hand. ${ }^{8}$ These cameras can easily be concealed in a briefcase, a lamp, a plant, ${ }^{9}$ a lunch box, ${ }^{10}$ a television, ${ }^{11}$ or even a teddy bear. ${ }^{12}$ Miniature still cameras can be disguised as cigarette lighters ${ }^{13}$ or watches. $^{14}$ Moreover, special

- See James G. Carr, The Law of Electronic Surveillance \$ 2.5(a) (Clark Boardman, 2d ed 1991) (discussing differences between conventional and electronic searches).

- Congress enacted Title III of the Omnibus Crime Control and Safe Streets Act, 18 USC $\S \S 2510-2521$ (1988) (“Title III") in 1968 to regulate government eavesdropping and wiretapping. At the time, electronic visual surveillance was not a great threat to Fourth Amendment interests, because the technology outlined later in this section did not yet exist.

7 Justice Douglas said that a statute authorizing electronic surveillance "in effect, places an invisible policeman in the home." Berger, 388 US at 65 (Douglas concurring).

- Electronics City, a discount electronics retailer, advertises a Sony CCD TR7 8mm video camera, weighing less than two pounds, for less than $\$ 850$. NY Times A34 (May 5, 1991).

- Office of Technology Assessment, Federal Government Information Technology: Electronic Surveillance and Civil Liberties 63 (GPO, 1985) (“OTA Report").

${ }^{10}$ Craig Brown, Shrinking the Shrinkage Problem, Oregon Bus 15 (Nov 1990).

11 Carl S. Kaplan, Spies Like Us, Newsday 80 (June 10, 1990). One of the video cameras used in the now-famous video surveillance of Washington, D.C. Mayor Marion Barry was probably hidden behind the screen of a television. Paul Valentine, Analyst Calls Quality of Tape 'Actually Pretty Good', Wash Post D7 (July 2, 1990).

12 Spy Tech, a Manhattan-based company, sells a stuffed teddy bear with a video camera peering through its navel for about $\$ 1,200$. Kaplan, Newsday at 80 (cited in note 11 ).

${ }^{13}$ Brown, Oregon Bus at 15 (cited in note 10).

14 Stan Sinberg, Playing It Safe, Chi Trib Mag 18 (May 27, 1990); Once-Secret East, West German Spy Camera Now on Auction, LA Times A18 (Oct 6, 1990). 
lenses can make a camera even more secret. A camera fitted with a "pinhole lens" is virtually undetectable because the aperture of its conical lens has a diameter of less than $1 / 8$ of an inch. ${ }^{15}$ Cameras equipped with such lenses can be hidden in sprinkler heads, heating vents, or even clocks. ${ }^{16}$

One of the most intimidating aspects of modern surveillance technology is its ability to capture images in the dark. For example, infrared television cameras can detect infrared radiation and convert it to a detailed, high-resolution visual image. ${ }^{17}$ Pocketsized infrared cameras are available on the retail market. ${ }^{18}$ Furthermore, computer imaging systems can create images without having to "see" at all. Technicians can use sound waves or microwave technology to gather huge data sets, which computers can then transform into visual images. ${ }^{19}$ For example, the United States government uses microwave technology for some of its more sophisticated surveillance satellites. From space, the satellites can "see" objects as small as three feet across through clouds and in darkness. ${ }^{20}$ This technology creates the very real possibility that the government will soon be able to gain detailed visual images of private dwellings without even installing a camera or entering the premises.

With miniature cameras, infrared technology, and (perhaps soon) computer imaging systems, officials can monitor enclosed areas with any of a variety of techniques, and under any lighting conditions. ${ }^{21}$ While these technologies undoubtedly provide bene-

15 Conversation with Michael Hoffman of Paymaster Associates, Inc., a spy technology company in Whitefish Bay, Wisconsin (Jan 1990). See also Dave Jensen, Inside Job: Employers Boost Worker Surveillance with High-Tech Tools, Bus J-Milwaukee 10 (Nov 5, 1990); People v Dezek, 107 Mich App 78, 308 NW2d 652, 655 (1981) ("needle-point" lens used to monitor stalls in public restroom).

${ }^{16}$ Paymaster Associates sells such a clock for $\$ 700-\$ 800$. Conversation with Michael Hoffman (cited in note 15). Foremost Security Products, Inc. of Milwaukee will rent a survelllance system that includes a camera with a pinhole lens for approximately $\$ 200$ per month. Jensen, Bus J-Milwaukee at 10 (cited in note 15).

17 See Note, 3 Hastings Const L Q at 268 (cited in note 4); OTA Report at 63 (cited in note 9).

${ }_{18}$ Spytech offers such a device. Sinberg, Chi Trib Mag at 18 (cited in note 14).

${ }^{19}$ Gina Kolata, Shaping Floods of Data, Computers 'See' the Unseen, NY Times C1 (Nov 20, 1990).

${ }_{20}$ William E. Burrows and John Free, Space Spies; U.S. Surveillance Satellites Give Detailed Images, Pop Science 60 (Mar 1990).

${ }^{21}$ It is arguably alarmist to discuss the available surveillance technology without discussing whether the technology is actually utilized by law enforcement officials. The Supreme Court, however, performed such an inquiry in Berger, 388 US at 46-47. The Court began its consideration of the constitutionality of a New York wiretap statute by reviewing the various kinds of "sophisticated electronic devices" that had been developed which were 
fits to law enforcement, the risk to the public's interest in personal privacy is uncomfortably high. A person's activities, carried on alone in her own home, are now subject to government scrutiny. A person may turn off the lights, close the curtains, mute her voice, and shrink into the deepest recesses of her home--yet these acts may not gain her privacy. ${ }^{22} \mathrm{~A}$ person subject to electronic visual surveillance cannot protect herself. The Fourth Amendment is her only protection.

\section{Fourth Amendment Surveillance Cases in the SUPREME COURT}

Because the Fourth Amendment is the individual's only protection against the intrusive power of EVS, this section explores how the Supreme Court applies the Fourth Amendment in surveillance cases in general..$^{23}$ The threshold question in Fourth Amendment inquiries is whether a specific government act constitutes a search. A search occurs when government surveillance violates an individual's "reasonable expectation of privacy."24 If the act is a search, the Fourth Amendment mandates two separate but related requirements. ${ }^{25}$ First, search warrants must be supported by a showing of probable cause, and must describe with particularity

\footnotetext{
"capable of eavesdropping on anyone in almost any given situation." Id. The Court was astute in starting its analysis this way, for the measure of danger to Fourth Amendment interests is not capped by the level of technology actually used in any specific case, but by the technology that government could bring to bear.

22 This comes at a time when, according to a recent Louis Harris and Associates Poll, the American public is more concerned about its privacy than at any time in the last twenty years. Aurora Mackey Armstrong, Private Eyes, Private Lives, LA Times J10 (July 19, 1990).

${ }^{23}$ The Supreme Court has not yet heard a case dealing specifically with EVS. See Section III for lower court approaches.

${ }^{24}$ This is Justice Harlan's famous paraphrase of the majority's holding in Katz v United States, 389 US 347 (1967). To determine when such a reasonable expectation exists, Justice Harlan proposed a two-part test. First, the individual must have "exhibited an actual (subjective) expectation of privacy." Id at 361 (Harlan concurring). Second, the individual's "expectation" must be "one that society is prepared to recognize as 'reasonable." Id. The Supreme Court adopted Justice Harlan's test in Smith $v$ Maryland, 442 US 735, 740 (1979).

${ }_{25}$ There is a difference of opinion concerning whether there are indeed two tests. See John Wesley Hall, Jr., Search and Seizure §§ 1:3, 1:10, 5:5 (Lawyers Co-op, 1982) (uncertainty exists whether two clauses are to be read together or separately; Fourth Amendment law "in flux"). The nuances of this dispute are beyond the scope of this Comment. While a Fourth Amendment analysis of EVS is easier to conceptualize under the "two test" theory, it is not necessary to do so. If the reader chooses to see the reasonableness inquiry as a part of the warrant requirements, the analysis for EVS would not change significantly.
} 
"the place to be searched, and the people or things to be seized." The second test is one of reasonableness, or more precisely, of absence of unreasonableness, for the Fourth Amendment protects individuals from "unreasonable searches and seizures."27

\section{A. The Warrant Requirements}

The warrant requirements mitigate the danger of government intrusions by forcing law enforcement officials to gain approval from a neutral magistrate before conducting a search. Magisterial approval is granted only if the officials meet the probable cause requirement by showing that there is a substantial probability that certain items are evidence of crime and that these items can be found at a certain place at a specific time. ${ }^{28}$ The Court has construed the Fourth Amendment to require a magistrate reviewing an application for a search warrant to have "a 'substantial basis for ... conclud[ing]' that a search [will] uncover evidence of wrongdoing . . ..."29

The magistrate may grant the application only if the warrant satisfies the particularity requirement as well. ${ }^{30}$ The Framers of the Fourth Amendment included the particularity requirement to protect the public from the dangers of general warrants, ${ }^{31}$ which allow law enforcement officials excessive discretion to search indiscriminately a person's property in hopes of finding evidence of criminal activity. The particularity requirement has been "modernized," and continues to be an important component of Fourth Amendment protections in an era of surveillance technology that would astound the Framers. In Berger $v$ New York, ${ }^{32}$ the Supreme Court struck down a New York statute allowing electronic surveillance without strict regulation because the Court found that the infringements on privacy allowed by the statute were "equally of-

${ }^{26}$ US Const, Amend IV.

27 Id.

28 Yale Kamisar, Wayne R. LaFave, and Jerold H. Israel, Modern Criminal Procedure 280 (West, 6th ed 1986).

${ }^{29}$ Illinois $v$ Gates, 462 US 213, 236 (1983) (quoting Jones v United States, 362 US 257, 271 (1960))

30 " $[\mathrm{N}]$ o Warrants shall issue, but [those] . . . particularly describing the place to be searched, and the persons or things to be seized." US Const, Amend IV.

${ }^{31}$ Marron v United States, 275 US 192, 195-96 (1927), overruled on other grounds by Harris v United States, 331 US 145 (1947); Berger, 398 US at 58. See also Philip B. Kurland and Ralph Lerner, 5 The Founder's Constitution 237 (Chicago, 1987) (listing provisions in early state constitutions of Virginia, Maryland, and Massachusetts requiring particularity as answer to dangers of general warrants).

${ }^{32} 388$ US 41 (1967). 
fensive" as those of a general warrant. ${ }^{33}$ The Court established strict requirements for electronic surveillance, limiting the use of intrusive technology to only the "most precise and discriminate circumstances"34 and then only with "judicial supervision" and "protective procedures."

In interpreting the particularity requirement for audio surveillance, the Court said that a magistrate must measure the warrant application according to four guidelines. First, the warrant must particularly describe the crime to which the surveillance relates, the communications or information sought to be intercepted, the place where the interception is to occur, and the people whose conversations are to be seized..$^{36}$ Second, the search must seek to minimize the government surveillance of people unconnected to the crime under investigation. ${ }^{37}$ Third, the warrant may allow surveillance for only a limited duration, with the opportunity of extending the surveillance upon a new showing of probable cause. ${ }^{38}$ Finally, the warrant may allow the search to proceed without prior or concurrent notice to the people searched only where "exigent circumstances" are shown. ${ }^{39}$ The Berger Court implied that these four particularity requirements become more important as the sophistication and potential intrusiveness of the surveillance technology in question increases. ${ }^{40}$

In 1968, Congress codified the Berger particularity requirements and sought to regulate government eavesdropping and wiretapping in Title III of the Omnibus Crime Control and Safe Streets Act ("Title III"). ${ }^{41}$ Each of the four Berger factors has its analogue in the statute. ${ }^{42}$ Congress interpreted the exigency requirement to mandate "a full and complete statement as to whether or not other investigative procedures have been tried and failed or why they reasonably appear to be unlikely to succeed if

${ }^{33}$ Id at 58,64 .

34 Id at 56 (quoting Osborn v United States, 385 US 323, 329 (1966)).

ss Id at 60.

${ }^{36}$ Id at 56-59.

37 Id.

ss Id at 57.

39 Id at 60 .

10 Id at 56 ("The need for particularity ... is especially great in the case of eavesdropping. By its very nature eavesdropping involves an intrusion on privacy that is broad in scope. ... [S] [Sch devices ... impose[] 'a heavier responsibility on this Court. . . '").

11 USC \$\$ 2510-2521 (1988).

42 The particular description requirement is 18 USC $\S 2518(1)(b)$, the minimization and duration requirements are $\S 2518(5)$, and the exigency requirement is $\S 2518(1)$ (c). 
tried or to be too dangerous." ${ }^{\text {43 }}$ Courts refer to this requirement as a "necessity"44 or "least intrusive means"45 standard. If other means of surveillance are likely to fail, are excessively dangerous, or are unavailable, the courts generally rule that audio surveillance meets this least intrusive means requirement. ${ }^{46}$

In addition to the four particularity requirements, Congress also included in Title III numerous provisions to ensure audio surveillance would be performed only with "adequate judicial supervision" and "protective procedures," as Berger had required. These non-particularity provisions limit the use of audio surveillance to investigations of serious crimes, establish measures to increase confidentiality and to reduce official abuse, and ensure post-investigation notice to the persons targeted by the surveillance. ${ }^{47}$ Clearly, therefore, Congress did more than simply codify Berger's particularity requirements in Title III. The Act embodied a more comprehensive enactment of Berger's principles, and represented a careful legislative balancing of the costs and benefits of electronic surveillance.

\section{B. The Reasonableness Inquiry}

For much of the Supreme Court's history, the Court conflated the reasonableness inquiry and the warrant inquiry. Without a technically sufficient warrant, a search was per se unreasonable. ${ }^{48}$ Conversely, a search conducted pursuant to a warrant that met the probable cause and particularity requirements was, for all intents and purposes, constitutionally permissible; the Court paid little attention to the reasonableness clause as imposing independent constraints. ${ }^{49}$

The Court increasingly identified more exceptions to the warrant clause, balancing the various interests involved in order to determine when to relax the warrant requirements. ${ }^{50}$ At first, balancing was limited to these recognized exceptions, ${ }^{51}$ to administrative

4318 USC \& 2518(1)(c).

“ See, for example, United States v Mesa-Rincon, 911 F2d 1433, 1442 (10th Cir 1990).

${ }^{4}$ See, for example, United States v Biasucci, 786 F2d 504, 510 (2d Cir 1986).

${ }^{46}$ See Carr, The Law of Electronic Surveillance at $\$ 4.4$ (d) (cited in note 5).

4718 USC §§ 2516(1), 2516(2), 2518(7), 2518(8)(a), 2518(8)(d).

18 "Searches conducted outside the judicial process, without prior approval by judge or magistrate are per se unreasonable under the Fourth Amendment-subject only to a few specifically established and well-delineated exceptions." Katz, 389 US at 357.

10 See Stephen A. Saltzburg, American Criminal Procedure 34 (West, 3d ed 1988).

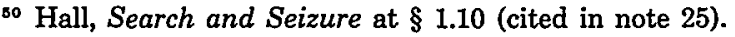

${ }^{81}$ See, for example, Terry $v$ Ohio, 392 US 1 (1968). 
searches, ${ }^{52}$ and to intrusions involving some lower degree of individualized suspicion. ${ }^{53}$ But as time went on, this balancing of interests came to be seen as embodying the separate, but related requirements of the reasonableness clause of the Fourth Amendment. ${ }^{54}$ Now, even though there remains a strong presumption that a warrantless search is unreasonable, ${ }^{55}$ the presence of a warrant is not always determinative for finding reasonableness. The Court has stated that "there can be no ready test for determining reasonableness other than by balancing the need to search against the invasion which the search entails." The Court now describes this "balancing of competing interests" as "the key principle of the Fourth Amendment." So while the warrant clause undoubtedly imposes its own set of constitutional requirements, the reasonableness clause embodies separate and additional requirements that the intrusion to personal privacy be balanced against the law enforcement objectives.

For this reason, courts can invoke the reasonableness balancing not only to permit warrantless searches, but also to do the opposite-to invalidate a search as unreasonable even if supported by a technically sufficient warrant. ${ }^{58}$ Justice Douglas wrote that "a warrant that is technically adequate . . . does not make every search constitutional." Jo Judge Posner has asserted that "a search could be unreasonable, though conducted pursuant to an otherwise valid warrant, by intruding on personal privacy to an extent disproportionate to the likely benefits from obtaining fuller compliance with the law."

${ }^{32}$ See, for example, Camara $v$ Municipal Court, 387 US 523 (1967).

${ }^{83}$ See, for example, Bell $v$ Wolfish, 441 US 520 (1979).

o4 See Hall, Search and Seizure at $\$ 1.3$ (cited in note 25).

ss See, for example, United States v United States District Court, 407 US 297, 315 (1972).

Bs Camara, 387 US at 536-37. See also Terry, 392 US at 19, 20-21.

${ }^{87}$ Tennessee v Garner, 471 US 1, 8 (1985) (quoting Michigan v Summers, 452 US 692, $700 \mathrm{n} 12$ (1981)).

ss See Hall, Search and Seizure at § 1:3 (cited in note 25).

so Berger, 388 US at 67 (Douglas concurring). See Osborn, 385 US at 350 (Douglas dissenting) (" $[\mathrm{A}]$ validly executed warrant does not necessarily make legal the ensuing search and seizure.") (citing Boyd v United States, 116 US 616 (1886)). For a more historical case supporting Justice Douglas's assertion, see Gouled v United States, 255 US 298 (1921) (some searches impermissible even with a technically proper warrant), overruled on other grounds by Warden v Hayden, 387 US 294 (1967). Justice Douglas believed that wiretapping and bugging could never pass the balancing test, even with a valid warrant. See Gelbard v United States, 408 US 41, 62 (1972) (Douglas concurring); Cox v United States, 406 US 934, 934-35 (1972) (Douglas dissenting from denial of cert); Berger, 388 US at 64-68 (Douglas concurring); Osborn, 385 US at 340-54 (Douglas dissenting).

so Torres, 751 F2d at 883. 
In a Fourth Amendment case not involving surveillance, the Supreme Court made it clear that the reasonableness test can prohibit a search even if supported by a proper court order. In Winston $v L e e,{ }^{B 1}$ the Court held that a state cannot compel a person charged with a violent felony to undergo surgery to remove a bullet from beneath his skin, even if the bullet would be evidentiary at trial. Applying a balancing test, the Winston Court held that the surgery was so intrusive as to be unreasonable even if supported by a court order and if likely to be useful in prosecuting the defendant. $^{.2}$

\section{Lower Court Cases Considering EVS}

The Supreme Court has never heard a case in which the lower court had applied the reasonableness test or the warrant requirements to EVS. The Second, Fifth, Seventh, and Tenth Circuits have considered EVS cases, as have federal district courts in New York and California and state courts in New York and Maryland. The warrant requirements these courts claim to apply are largely consistent with each other. Namely, the courts apply the Berger requirements as interpreted by Title III. However, no court has applied all the Title III requirements to EVS. The ironic result is that video surveillance is effectively subject to fewer restrictions than is audio surveillance. Only the Seventh Circuit recognizes that a reasonableness balancing test might impose constraints on the use of EVS over and above the warrant requirements.

\section{A. The Seminal Case: United States $v$ Torres}

The most important EVS case to date is United States $v$ Torres ${ }^{63}$ in which the Seventh Circuit upheld the FBI's use of EVS to investigate an organization suspected of building bombs for use in "urban terrorism." tablish evidence of the bomb-making and to identify the terrorists. Judge Posner, writing for the court, balanced the FBI's need for EVS, measured by the availability of other evidence and the severity of the suspected crime, against the intrusion, measured by the type of premises under surveillance. Although recognizing that EVS is extremely intrusive, the court held that its use was reason-

${ }^{61} 470$ US 753 (1985).

62 Id at 766.

${ }^{83} 751$ F2d 875 (7th Cir 1984).

64 Id at 883. 
able because the terrorists were dangerous criminals, ready to "kill in gross," and because the premises under surveillance were not used as residences, but rather, were "dedicated exclusively to illicit business." able under the circumstances, Torres is important for the Court's recognition that a reasonableness balancing test could impose standards separate from the warrant requirements. In fact, Judge Posner suggested that EVS was so intrusive that it might be necessary to ban its use in homes, at least with respect to some crimes. ${ }^{66}$

In interpreting the Berger warrant requirements for the EVS context, the Seventh Circuit in Torres looked to Title III for guidance and held that the statute "provides the measure of the government's constitutional obligation" of particularity for EVS. ${ }^{67}$ The court incorporated Title III's rules on least intrusive means, particular description, minimization, and limited duration into EVS law. The Court felt that EVS met the least intrusive means requirement because audio surveillance would not have been successful. ${ }^{88}$ Specifically, the suspects had taken steps to defeat any attempts at audio surveillance by working in silence or playing the stereo loudly. ${ }^{68}$

Judge Posner refused to borrow Title III's additional requirements, however. He argued that the remaining provisions of Title III did not codify any constitutional requirement, and thus should not govern EVS. ${ }^{30}$ Importantly, however, this part of Judge Posner's analysis is dicta. The FBI had submitted the application for EVS at the same time as an application for audio surveillance, and arguably had satisfied even the non-warrant requirements of Title III. ${ }^{71}$ Also importantly, the result in the case probably would have been the same even if the court had adopted the additional Title III requirements. ${ }^{72}$

\section{B. Other EVS Cases}

None of the other significant EVS cases used a reasonableness balancing test in determining whether EVS is constitutional.

${ }^{o s}$ Id.

s6 Id at 882

67 Id at 885 .

68 Id at 884 .

69 Id at 877 .

70 Id at 883 .

73 Id at 884 .

${ }^{72}$ Judge Cudahy concurred in the result, although he felt that all portions of Title III should govern EVS as a matter of statutory interpretation. Id at 886-95. 
Rather, they each adopted Berger as the measure of the Fourth Amendment warrant requirements. Except for one early state case, New York $v$ Teicher, ${ }^{73}$ they each used Title III to define the four Berger particularity standards, while refusing to adopt Title III's additional requirements.

Most of the cases involved investigations of drug trafficking or organized crime. ${ }^{74}$ The Second Circuit, in United States $v$ Biasucci, ${ }^{75}$ like the district courts in United States $v$ Andonian ${ }^{76}$ and United States $v$ Ianniello ${ }^{77}$, allowed EVS in federal investigations of organized crime. The Fifth Circuit, in United States $v$ Cuevas-Sanchez, ${ }^{78}$ upheld the use of EVS in an investigation of a narcotics distribution operation, as did the Maryland Court of Appeals in Ricks $v$ State. ${ }^{79}$

Two cases do not fit obviously in the organized crime or drug categories. In United States v Mesa-Rincon, ${ }^{\mathbf{8 0}}$ the Tenth Circuit upheld the use of EVS evidence to convict two defendants for counterfeiting. The New York Court of Appeals, in People $v$ Teicher ${ }^{81}$ upheld the use of EVS to gain evidence that a dentist was sexually molesting female patients while they were under anesthesia. ${ }^{82}$

The opinions in these cases authorized EVS in a variety of locations. Biasucci, Teicher, Ianniello, and Andonian allowed EVS in offices. Mesa-Rincon permitted EVS in a warehouse. As in

${ }^{73} 52$ NY2d 638, 422 NE2d 506 (1981). The Teicher court simply held that Title III did not apply to EVS, and used Berger and Katz to guide its analysis. Id at 513. Nevertheless, the rationale of the opinion is completely consistent with Title III's requirements.

${ }^{74}$ This is for several reasons. EVS is most useful in investigations of sophisticated organizations that are difficult for undercover agents to infiltrate or from which few participants defect. Also, EVS is helpful in gathering identity evidence, which is often crucial in these investigations.

7s 786 F2d 504 (2d Cir 1986).

76735 F Supp 1469 (C D Cal 1990).

${ }^{27} 621$ F Supp 1455 (S D NY 1985).

78821 F2d 248 (5th Cir 1987).

79312 Md 11, 537 A2d 612 (1988). For a detailed analysis of this case, see Note, Ricks v. State: Big Brother Has Arrived in Maryland, 48 Md L Rev 435 (1989).

so 911 F2d 1433 (10th Cir 1990).

81422 NE2d 506.

82 In addition to the cases outlined in the text, see also In the Matter of an Application of the United States for an Order Authorizing Interception of Oral Communications and Videotape Surveillance, 513 F Supp 421 (D Mass 1980). The court allowed EVS, but held that EVS should face restrictions "no less severe" than those Title III imposes on audio surveillance. Id at 423 . See also Dezek, in which the Michigan Court of Appeals struck down the use of EVS to gather evidence of sexual activity in a men's public restroom. The court held that the police officials had not limited the search to the "precise and discriminate circumstances" required by Berger. 308 NW2d at 657 . 
Torres, the Ricks court permitted EVS in an apartment. In Cuevas-Sanchez, the camera was installed on a pole overlooking the suspect's back yard.

\section{Fourth Amendment Standards Applied to EVS}

When officials use EVS in nonpublic areas ${ }^{83}$ and without the consent of a person present, ${ }^{84}$ the surveillance constitutes a search in most cases. Generally, EVS "discloses intimate associations, objects or activities otherwise imperceptible," a search if placed in any of a number of places. ${ }^{88}$ These would include homes, ${ }^{87}$ offices, ${ }^{88}$ some fenced yards, ${ }^{89}$ hotel rooms, and restroom stalls in public washrooms. ${ }^{90}$ Exceptions would be limited to those places where people would not have a legitimate expectation of visual privacy. ${ }^{91}$

In situations where EVS is a search, a court must apply both the particularity test and the reasonableness test to its use. This Section demonstrates how these tests should be applied in the

83 If an individual has "knowingly exposed" an act or object to the public, that act or object is not subject to Fourth Amendment protection. Katz, 389 US at 351 . If technological surveillance is to take place in areas like streets, where the target is open to public view, the target has no "reasonable expectation of privacy" because she has knowingly exposed herself to public view. See Clifford S. Fishman, Technologically Enhanced Visual Surveillance and the Fourth Amendment: Sophistication, Availability and the Expectation of Privacy, 26 Am Crim L Rev 315 (1988). This Comment does not deal with the surveillance of people in such circumstances.

84 Surreptitious recording of a conversation with the consent of one of the parties to the conversation does not constitute a search of the other party. See United States $v$ White, 401 US 745 (1971). At least one court has extended this "consent" exception to EVS. See People $v$ Henderson, $220 \mathrm{Cal}$ App 3d 1632 (1990). Department of Justice policy is that "[EVS] of private places where one party has consented to the surveillance, even if that party is an undercover agent or informer, is assumed to be legitimate." OTA Report at 62 (cited in note 9). See also Note, 3 Hastings Const L Q at 279 n 104 (cited in note 4) (questioning whether exception should extend). This Comment does not address this issue, and assumes that EVS is performed without the consent of any of the parties under surveillance.

ss California v Ciraolo, 476 US 207, 215 n 3 (1986).

${ }^{88}$ See generally Kamisar, LaFave, and Israel, Modern Criminal Procedure at 246 (cited in note 28 ).

${ }^{87}$ Ricks, 537 A2d 612.

Bo Teicher, 422 NE2d 506.

Bo Cuevas-Sanchez, 821 F2d 248. Clearly, some fences do not restrict public view. A reasonable expectation of privacy from visual surveillance would not exist in such a yard.

${ }^{\circ}$ Dezek, 308 NW2d 652. See also Idaho v Limberhand, 117 Idaho 456, 788 P2d 857 (App 1990) (man masturbating in public restroom stall may have reasonable expectation of privacy).

${ }_{91}$ One example would be where the video camera was placed to view persons in a public tavern, see Sponick v Detroit Police Department, 49 Mich App 162, 211 NW2d 674 (1973), overruled on other grounds by Rinaldi v Civil Service Commission, 69 Mich App 58, 244 NW2d 609 (1976). 
EVS context. When evaluating the warrant requirements, courts should tailor the Berger/Title III standards to EVS, and apply them more strictly than for less intrusive technologies. Within the reasonableness balancing, courts should look to the availability of evidence from other sources and the severity of the suspected crime. Lastly, courts should recognize that Title III embodies reasonableness requirements as well as warrant requirements, and should measure EVS against the Title III reasonableness requirements as well.

\section{A. The Warrant Requirements: Particularity}

The Fourth Amendment mandates particularity in the search warrant. ${ }^{92}$ This section focuses on the particularity requirements, and proposes how a judge should apply the four Berger standards-least intrusive means, particular description, minimization, and limited duration-to EVS. In general, the judge considering an EVS application should recognize two critical points. First, because EVS is by nature different from audio surveillance, the Berger/Title III standards should be tailored to EVS. Second, those standards should be stricter in EVS cases than in audio surveillance cases, because they become increasingly important the more intrusive the technology. This section applies the particularity requirements to the EVS cases described in Section III. Only Torres survives the analysis.

\section{Least intrusive means.}

Berger suggests that no greater invasion of privacy should be permitted than is necessary under the circumstances. ${ }^{93}$ Indeed, lower courts interpret Berger's exigency standard as creating a doctrine of "least intrusive means" when considering whether elec-

${ }^{92}$ The Constitution also requires a showing of probable cause. The Court has implied that this probable cause showing ought to be greater in cases of intrusive electronic surveillance. Berger, 388 US at 56. Judge Posner acknowledged this in Torres, where he said that judges take account of the varying intrusiveness of searches by requiring a higher degree of probable cause for more intrusive searches. Torres, 751 F2d at 882 . If Judge Posner is correct, judges should demand both a high level of suspicion and considerable information about the suspect to be monitored before they authorize EVS. These demands would mean that judges should grant EVS orders predominately in the later stages of an investigation, or at least after a significant portion of the investigation has taken place. See OTA Report at 66 (cited in note 9). Few other courts have acknowledged the possibility that the probable cause requirement is variable, however. Unfortunately, the question of variable probable cause in the context of EVS is beyond the scope of this Comment.

${ }^{93} 388$ US at 57. 
tronic surveillance meets the particularity requirement. ${ }^{94}$ The Second Circuit has stated that "the [Supreme] Court has long been critical of secret searches. Electronic surveillance cannot be justified unless other methods of investigation are not practicable."'9s The burden imposed by this standard increases in direct proportion to the intrusiveness of the surveillance technology. ${ }^{96}$ Thus, whenever a law enforcement objective can be accomplished by a conventional search and seizure, by a conventional search supplemented with audio surveillance, or by other investigatory techniques, a request by law enforcement officials to accomplish the same objective using EVS will fail to satisfy the least intrusive means requirement. The bottom line is that officials proposing to use EVS must make "a full and complete statement" "97 as to why all other alternatives are unavailable, unproductive, or exceptionally dangerous. ${ }^{98}$

Of course, some types of evidence are more probative of criminal activity than others, and law enforcement officials and juries generally will find video evidence quite persuasive. ${ }^{99}$ But the fact that a videotape may be more convincing to a jury than other kinds of evidence should not, by itself, justify the use of EVS. ${ }^{100}$ Rather, for a judge to authorize EVS, the investigators must need it to gather a type of evidence that is different in objective value-not simply in its power to influence a jury.

Because the product of EVS is visual information, officials generally use EVS to gather two general classes of evidence: evidence of a suspect's identity and evidence of human activity. ${ }^{101}$

24 See, for example, Mesa-Rincon, 911 F2d at 1442 (the government must use least intrusive means to obtain needed information). See also Title III, 18 USC $\S 2518(1)$ (c) (stating exigency standard in terms of least intrusive means requirement).

os United States v Tortorello, 480 F2d 764, 774 (2d Cir 1973) (citation omitted).

98 Berger, 388 US at 60 ("Such a showing of exigency, in order to avoid notice would appear more important in eavesdropping, with its inherent dangers, than that required when conventional procedures of search and seizure are utilized.") See also Mesa-Rincon, 911 F2d at 1442.

${ }^{97} 18$ USC $\$ 2518(1)$ (c).

${ }^{98}$ See Carr, The Law of Electronic Surveillance at $\$ 4.4(\mathrm{~d})$ (cited in note 5).

9 Criminals themselves acknowledge the impact video evidence can have. Jeff Gerth, Colombian Cocaine: Tracking Down Dealers, NY Times A1 (Apr 23, 1990).

${ }^{100}$ See Winston, 470 US 753.

${ }^{101}$ See Note, 3 Hastings Const L Q at 289-90 (cited in note 4). Officials could also use EVS to gather evidence of the presence of tangible objects in a specific location. No case to date has provided a clear example of EVS used for this purpose, however. EVS of an object is probably never necessary, given the other means of monitoring and searching for objects. A conventional search warrant is a very powerful tool, and will enable officials to seize the evidence in most cases. Indeed, if the officials do not want to remove the physical evidence, they may enter private property to photograph evidence without contemporaneous notice. 
Within the least intrusive means analysis, officials probably can best justify EVS when they need it to gather identity evidence. Video recordings are sometimes the best way to learn the identities of people involved in criminal activities, especially when the crimes occur in locations inaccessible to other forms of surveillance. EVS is more difficult to justify for gathering activity evidence, however. Most criminal activities either produce physical evidence of some kind or make victim testimony possible. Generally, the best case for EVS will be when the alleged crime cannot be expected to produce either physical evidence or victim testimony. These crimes often will be those acts that create no "result"-no physical evidence-and have no victim. ${ }^{102}$ When physical evidence or victim testimony is available, law enforcement officials must justify why the gathering of that evidence is not the least intrusive means of gathering evidence of the activity.

Courts often relax the least intrusive means standard to uphold the use of EVS. In investigating the loansharking activities in Biasucci, ${ }^{103}$ the government failed to explain why it needed EVS in addition to audio surveillance. At the time of the EVS application, the FBI had alleged that some sources had refused to testify, victim interviews were "unlikely" to be fruitful, and search warrants "were not expected to produce significant evidence at the time."104 The court accepted these assertions as "adequate facts" to satisfy the least intrusive means test for use of EVS. ${ }^{108}$ However, at trial, the FBI produced evidence from victim testimony, undercover agents, over a hundred tape-recorded conversations, and various records and documents seized from the defendants' offices. ${ }^{106}$ Though the evidence at trial might not be a completely accurate way to judge whether EVS was justified in the first place, the existence of this evidence does make it appear that the FBI's original "full and complete statement" to justify EVS did not properly represent the other investigatory means available.

United States $v$ Villegas, 899 F2d 1324, 1336-38 (2d Cir 1990). Also, the use of tracking devices, like that used in United States v Karo, 468 US 705, 715 (1984) (location-monitoring beeper), often will be more beneficial to law enforcement officials in detecting the presence of specific objects than EVS.

102 EVS of "victimless" crimes, like prostitution or personal drug use, however, will be difficult to justify under the reasonableness analysis because these crimes are not regarded as "serious" ones. See text at notes 162-65.

103786 F2d 504.

104 Id at 511 .

105 Id at 512.

${ }^{108}$ Id at 507. 
In Cuevas-Sanchez, ${ }^{107}$ the court failed to hold EVS to the least intrusive means test. The prosecution argued that EVS did not constitute a search when a camera was placed on a pole overlooking the defendant's fence, because the activities viewed by the camera could be seen from the street or by simply looking over the fence. ${ }^{108}$ The court correctly held that EVS did constitute a search, noting the defendant's expectation of privacy, the indiscriminate nature of EVS, and the serious intrusion of the surveillance. ${ }^{109} \mathrm{Un}$ fortunately, the court failed to realize that the government, in effect, had defeated its own least intrusive means argument. By arguing that EVS was not a search because the agents could have viewed the activity simply by peeking over the fence, the government admitted "that conventional surveillance would have revealed the activities that led to Cuevas's arrest."110 Moreover, even though EVS was used only to spot the defendant carrying a garbage bag (which the police believed to contain drugs), the court did not explain why a physical search of the property would not have satisfied the same law enforcement needs.

In Mesa-Rincon, ${ }^{111}$ the court wrongly allowed EVS of a suspected counterfeiting operation when other methods of investigation were readily available. The Secret Service could have used a physical search to seize the actual counterfeit bills and an impressive array of other damning physical evidence. ${ }^{112}$ Yet the government in its application did not discuss why such a search would have been impractical. ${ }^{113}$

In Mesa-Rincon, as in Biasucci and Cuevas-Sanchez, the courts failed adequately to consider the least intrusive means requirement of Berger and Title III. In each case, the court failed to justify the intrusion of EVS by explaining why conventional inves-

107821 F2d 248.

108 Id at 250.

108 Id at 250-51.

110 Id at 250 .

111911 F2d 1433.

112 The government supported its showing of probable cause for the use of bugging equipment by arguing that the sound of the printing presses would drown out the conversations. Id at 1443. The government failed to explain, however, why such an audio clue would not give the perfect "tip-off" they needed to perform a physical search and seize the counterfeit bills themselves.

113 Id at 1445. The Secret Service did try to justify EVS in Mesa-Rincon on grounds that it was the least intrusive means of gathering evidence of the identities of the suspect's accomplices. Nothing in the opinion, however, suggests that EVS was ever used for that purpose. 
tigative procedures would have been unavailable, unproductive, or exceptionally dangerous.

\section{Particular description.}

The Berger Court emphasized that an application for electronic surveillance must describe particularly the place to be put under surveillance, the identity of the person under surveillance, and the intangible property-the conversations - to be seized. ${ }^{114}$ Without a particular description, the warrant "leaves too much to the discretion of the officer executing the order."115 A particularized warrant provides guidelines for the officers so they will know in advance what they are looking for, and when they must stop.116 Because the dangers of official discretion are so great with EVS, the requirements of particular description are especially important in the EVS context. This Section explains how a judge should evaluate the descriptions of the targeted place, activity, and person.

a) Targeted place. An EVS application and order should be required to specify the precise location within the premises where the officials wish to install EVS equipment.117 If an officer were not required to specify the exact location of the viewing device, she could exercise her own discretion in placing the camera within the structure. When an EVS warrant is based on the activities to be monitored rather than the location to be watched, this discretion is problematic under Berger, because the officer could install the device in areas where the surveillance would be quite unlikely to reveal the target acts. ${ }^{118}$

If the officer submitting the application cannot identify the specific location where the camera will be placed, the judge has two. choices. First, she can refuse to grant the application, pending a more specific description of the location. Second, she can assume that all parts of the structure will be subject to surveillance, unless areas are explicitly excluded. An intrusion of such magnitude, however, should increase the strictness with which she applies the other three Berger requirements. Or, such an intrusion might sim-

11388 US at 58-59. See also Title III, 18 USC $\S 2518(1)$ (b).

$115388 \mathrm{US}$ at 59.

${ }^{116}$ Carr, The Law of Electronic Surveillance at $\$ 2.5(c)(1)(C)$ (cited in note 5).

11 See Note, 3 Hastings Const $L Q$ at 283 (cited in note 4).

118 Berger, 388 US at 59 (One risk of general warrants is that they leave "too much to the discretion of the officer. . .."). See also Zurcher $v$ Stanford Daily, 436 US 547, 564 (1978) ("Where presumptively protected materials are sought to be seized, the warrant requirement should be administered to leave as little as possible to the discretion or whim of the officer in the field."). 
ply make the search an unreasonable one, depending on the nature of the structure, the severity of the crime, and the availability of other evidence.

For example, the warrant in Torres listed only the address, and authorized cameras in every room of the safe house. ${ }^{119}$ This was reasonable, given that no one used the safe house as a home and the severity of the suspected crime was great. In Biasucci, the EVS orders listed only the suite number of the office where the suspected loansharking activity was taking place. ${ }^{120}$ In Teicher, the order stated that the camera was to be placed within the dentist's office, but failed to specify the particular room. ${ }^{121}$ These orders were probably reasonable, however, given the limited variety of activity that usually takes place within business premises and the corresponding decrease in the expectation of absolute privacy. On the other hand, some reports of the Marion Barry surveillance suggest that at least one camera was hidden in the bathroom of the hotel suite where the surveillance took place. ${ }^{122}$ Putting aside the possible consent exception, ${ }^{123}$ such an intrusive surveillance would not be reasonable to catch someone smoking crack. The key consideration for the judge is the level of discretion left to the officer to seize evidence of activity not related to the purpose of the surveillance.

b) Targeted activity. The warrant also must describe with particularity the target activity of the surveillance. First, the activity described must be directly related to the stated purpose of the surveillance. ${ }^{124}$ Second, the description of the activity must be specific; the judge must be sure the government is not on an EVS fishing expedition. The application in Ricks failed both of these tests. In an investigation of an alleged "major, multi-dimensional illegal narcotics distribution organization" the application described the activity to be seized by EVS as conduct "pertaining to drug-related activities." ${ }^{125}$ There are two problems with this

${ }^{120} 751 \mathrm{~F} 2 \mathrm{~d}$ at 884 . See also Ricks, $537 \mathrm{~A} 2 \mathrm{~d}$ at 616.

$120786 \mathrm{~F} 2 \mathrm{~d}$ at $511 \mathrm{n} 8$.

121422 NE2d at 514.

122 See Valentine, Wash Post D7 (cited in note 11).

${ }^{123}$ See note 84. Barry's companion in the hotel room was an FBI informant. See Michael York and Michelle L. Norris, Mysterious Moore to be Asked of Relationship with Barry, Wash Post A1 (June 25, 1990).

${ }_{124}$ See Carr, The Law of Electronic Surveillance at $\$ 4.4$ (d) (cited in note 5) ("Intrusions under the Fourth Amendment are limited by the justification upon which they are based.").

${ }^{125} 537$ A2d at 614,621 . 
description. First, the activities that EVS could capture on tape might have little relation to the purpose of the surveillance, which was to determine the method of interstate supply and the locations of other stash houses. ${ }^{126}$ Second, the description was too broad. There are many drug-related activities, both legal and illegal, that do not provide evidence of major narcotics operations. Evidence that a person has taken an aspirin, or even smoked a joint, does not prove that he is a drug kingpin.

To give effect to a particular description of the target activity, the officials operating the EVS equipment must follow strict procedures to ensure the activity viewed is the activity described. ${ }^{127}$ Otherwise, EVS is certain to capture the unrelated activities of the targets. During physical searches pursuant to a search warrant, the officials may not seize items unrelated to the items they are authorized to seize. ${ }^{128}$ During audio electronic surveillance, the officials must end their surveillance of unrelated, innocent conversations or sounds as soon as they realize that the conversation or sound is unrelated to those they are authorized to hear. ${ }^{129}$ With EVS, the procedures should be even stricter. The officials could use other forms of surveillance as a screening device and only use EVS when there is some indication that the described activity is occurring. ${ }^{130}$ Also, strictly limited spot monitoring, perhaps only a few seconds of viewing at a time, might be permissible in some circumstances. ${ }^{131}$ In any event, the key is first, for the judge to authorize the recording of a specific activity, and second, for the offi-

\footnotetext{
${ }^{128}$ Id at 614.

${ }^{127}$ These procedures overlap with those required by minimization concerns. See text at notes 141-50.

${ }^{128}$ An exception to this rule in physical searches is the plain view doctrine. A law enforcement official may seize a physical piece of evidence unrelated to the items listed in the search warrant if they fall "in the plain view of an officer who has a right to be in the position to have that view ...." Harris v United States, 390 US 234, 236 (1968).

${ }^{129}$ See Title III, 18 USC $\$ 2518(5)$. It is unclear to what extent the plain view doctrine extends to audio surveillance. See generally Note, Electronic Surveillance and Conversations in Plain View: Admitting Intercepted Communications Relating to Crimes not Specified in Surveillance Order, 65 Notre Dame L Rev 490 (1990).

${ }_{130}$ For example, in Mesa-Rincon, the Secret Service sought to gain video evidence of counterfeiting activity. The investigators could have used an audio bug to learn when relevant conversations were taking place, or (by the sound of the printing presses) when the actual counterfeiting was occurring. A screening procedure such as this would have ensured that only the described activities were captured by the surveillance, and would have prevented the minimization problems described in the next section. See note 147.

131 For a description of recommended spot-monitoring procedures for audio surveillance, see Carr, The Law of Electronic Surveillance at \$ 5.7(c) (cited in note 5).
} 
cials to use EVS only in a "precise and discriminate" way to capture that specific activity on video. ${ }^{132}$

c) Targeted person. The requirement of particular description of the identity of the targets is especially problematic in the EVS context. For regular physical searches, "as a constitutional matter, [search warrants] need not even name the person from whom the things will be seized."133 While officials requesting audio surveillance need only name their targets if their identities are known, ${ }^{134}$ courts should be stricter for EVS, and generally should require names or identity-specific descriptions of the people to be monitored.

Regulations should be stricter for EVS for two reasons. First, EVS is different not only in degree but in kind from other types of searches. With physical and audio searches, there is a distinction between the "property" to be seized and the person from whom the property is gathered. With EVS, it is the identity of the person herself (or more precisely the visual image of the person) that the government seizes. Courts must remember that "the Fourth Amendment protects people, not places."136 Second, EVS automatically subjects every person in view to a search, based only on their presence in a specific area. ${ }^{136}$ Yet Ybarra $v$ Illinois ${ }^{137}$ prohibits searches of people based simply on their presence in a place that is legally subject to search. A law enforcement official cannot subject someone to the intrusion of a search without a belief specific to the person that a search is justified for that person. ${ }^{138}$ For EVS, therefore, the targets of the surveillance must be only the named or specifically described people.

\footnotetext{
132 The plain view doctrine should have only very limited applicability to EVS. Because of the greater and more indiscriminate intrusion, there is a greater likelihood that officials will discover evidence of unparticularized crimes using EVS than with conventional searches or audio surveillance. If the evidence they gain through EVS is readily allowed into court regardless of its connection to the crime which provided the basis for probable cause, law enforcement officials will have incentives to exceed the limitations of the warrant. The potential for abuse is especially great with EVS. See Justice Douglas's concurrence in Berger, 388 US at 64-68. See also Note, 65 Notre Dame L Rev at 525-33 (cited in note 129); Comment, Video Surveillance-Big Brother May Be Watching You, 21 Ariz St L J 445, 458 (1989).

${ }^{138}$ Zurcher, 436 US at 555 (citing United States $v$ Kahn, 415 US 143, 155 n 15 (1974)).

${ }_{134} 18$ USC $\$ 2518(1)(b)$. See also United States $v$ Donovan, 429 US 413, 427 n 15 (1977) (conversations of unnamed persons can be overheard without violating Constitution). ${ }^{135} \mathrm{Katz}, 389$ US at 351.

${ }^{138}$ See Carr, The Law of Electronic Surveillance at $\$ 2.5(\mathrm{c})(2)$ (cited in note 5). See also United States v Taketa, 923 F2d 665, 675 (9th Cir 1991) (EVS is a search of anyone in camera's view).

${ }^{137} 444$ US 85 (1979).

${ }^{238}$ Id at 91.
} 
Of course, when the purpose of the surveillance is to gather evidence of the identity of people involved in criminal activity, a strict requirement for describing the identity of the target would be practically impossible to satisfy. A judge considering an EVS application could pursue several options. First, the judge could waive the naming of the particular person if the mere presence in the location of the surveillance would provide probable cause for the search. Ybarra allows this. ${ }^{139}$ For example, in Torres, the judge could reasonably assume that anyone who had access to the safe house would have knowledge of the bomb-making, and was thus a proper subject of video surveillance. Second, the judge could allow the use of EVS whenever at least one named or described target is present. Third, the judge could mandate that the application describe the situation in which the targets would appear, so that officials operate the equipment only when the people within the range of the camera are sure to be the targets of the surveillance. In effect, the judge could waive the identity description when the circumstances surrounding the surveillance would identify the target.

The field procedures to enforce the identity specification would be similar to those suggested earlier to limit EVS to a particular activity. For example, officials could use audio surveillance as a screening device, and operate the EVS equipment only when the audio surveillance establishes with certainty that the target is present.

\section{Minimization.}

The particularity requirement works hand in hand with the minimization requirement, which requires that the surveillance "be conducted in such a way as to minimize" the gathering of information unrelated to the investigation. ${ }^{140}$ While the particular description requirement mandates that the official identify the targets of surveillance, the minimization requirement is in effect the negative statement of the same rule. It demands that the officials protect from surveillance those activities and individuals not targeted by the warrant. ${ }^{141}$

Regardless of whether one thinks of minimization procedures as the enforcement mechanism for a particularity requirement or as checks on potentially overbroad descriptions, it is clear that the

\footnotetext{
139 Id at $90 \& \mathrm{n} 2$.

${ }^{140}$ See 18 USC § 2218(5); Carr, The Law of Electronic Surveillance at § 5.7(a) (cited in note 5).

${ }^{142}$ See Berger, 388 US at 59.
} 
Berger court considered minimization very important. The New York statute invalidated in Berger permitted seizure of "the conversations of any and all people coming into the area covered by the device ... indiscriminately and without regard to their connection with the crime under investigation."142 This, the Court held, was the electronic equivalent of a general search. ${ }^{143}$ The nature of EVS makes the minimization requirement very difficult to satisfy, ${ }^{144}$ because the danger of indiscriminate seizure of images of people without "regard to their connection with the crime under investigation"148 is uncomfortably high. In spite of this, or because of it, courts have disregarded the tough Berger minimization language in their consideration of EVS cases. The Biasucci court upheld EVS that recorded the movements of all people who entered the defendant's offices over a sixty-day period. ${ }^{146}$ In Mesa-Rincon, the EVS monitored an intimate act of an unknown person. ${ }^{147}$ And in Andonian, the cameras recorded all activities at the defendants' business for three months, ${ }^{148}$ including the "random comings and goings of a variety of people."149 The EVS in each of these cases should have failed the minimization requirement.

\section{Limited duration.}

The limited duration requirement ensures that a surveillance does not become "the equivalent of a series of intrusions, searches, and seizures pursuant to a single showing of probable cause."150 Title III prohibits audio surveillance for any period "longer than is necessary to achieve the objective of the authorization" or in any event "longer than thirty days."151 Extensions are possible, however, with a renewed showing of probable cause. ${ }^{152}$

142 Id.

163 Id at 58.

14 See Note, 3 Hastings Const $\mathrm{L} Q$ at $284-88$ (cited in note 4).

14s Berger, 388 US at 59.

$146786 \mathrm{~F} 2 \mathrm{~d}$ at 507-08, $508 \mathrm{n} 3$.

147 The officials operating the surveillance equipment observed an "act of masturbation" by an unknown male. 911 F2d at 1435. Despite that fact, the court held that the minimization requirement was satisfied by the EVS order, which required that the equipment be turned off when named suspects were not present in the building. Id at 1441 .

148735 F Supp at 1470.

140 Henry Weinstein, Videotape Rejected in Jewelry Mart Case, LA Times B1 (Mar 29, 1990).

180 Berger, 388 US at 59.

15118 USC \& 2518(5).

152 Id at $\S \S 2518(3), 2518(5)$. 
EVS warrants can be especially problematic when they are extended, because when all else is equal the level of intrusion is directly proportional to the length of time of the surveillance. Because we require a stricter analysis depending on the seriousness of the intrusion, each application for a renewal of an EVS warrant must meet progressively stricter requirements. While it most likely becomes easier to show probable cause as time goes by (because of the greater availability of damning evidence), the other requirements should become more stringent. For example, the particular descriptions should be even more precise than they were on the original application. The government is likely to have more information about the targets of the EVS and of the types of activity targeted, and should thus be required to be even more descriptive on the renewal application. Also, the reasonableness test requires that the more serious the intrusion, the more serious the crime must be to justify the surveillance. There may be crimes that can justify a one-month intrusion but that do not justify a two- or three-month intrusion.

\section{B. The Reasonableness Balancing}

After Berger and Katz, it is clear that no reasonableness balancing would allow EVS without a warrant. ${ }^{153}$ The key question, therefore, is under what circumstances EVS may be unreasonable even when supported by a technically sufficient warrant. This subsection seeks to answer this question by identifying the factors courts should consider when applying a balancing test to EVS. These factors come from two sources: Supreme Court decisions that implement the balancing test in other Fourth Amendment contexts, and Title III's non-warrant requirements, which define reasonableness for audio surveillance. The Supreme Court has identified several factors to be balanced in Fourth Amendment cases, including the severity of the crime and the availability of other evidence sufficient for arrest. Title III identifies several other factors, such as the sufficiency of procedures maximizing confidentiality and reducing opportunities for official abuse. These stan-

153 The Supreme Court held in these cases that because of the intrusiveness of audio surveillance, its use always required a warrant meeting strict particularity requirements. See also United States $v$ United States District Court, 407 US 297 (1972) (requiring warrant for audio surveillance even in national security cases). Because EVS is more intrusive than audio surveillance, it would be inconceivable to allow the use of EVS without a warrant that meets at least the standards specified in Berger. See Taketa, 923 F2d at 675 (warrantless videotaping violates Fourth Amendment reasonableness standard). 
dards-identified by the Supreme Court and Congress-should govern EVS analysis.

1. The Supreme Court's use of reasonableness balancing.

The Supreme Court has stated that to determine Fourth Amendment reasonableness, a court should balance the importance of the privacy interests, as measured by the level of intrusion of the search, against the strength of the government interests, as measured by the availability of other evidence and the severity of the suspected crime. Because of the severity of the intrusion, courts should analogize EVS to the surgical intrusion in Winston, and government interests should outweigh these important privacy interests only when EVS is necessary to gather evidence necessary to arrest someone suspected of a serious crime.

a) Privacy interests. The intrusiveness of EVS means that the privacy interests of those people subject to EVS will normally be very weighty in the reasonableness balancing. The Court made clear in Winston that some privacy interests are so great that a search infringing them might be unreasonable, even if supported by a court order. The Supreme Court asserted that a major factor in assessing the strength of these interests was the extent of intrusion upon the individual's "dignity interests in personal privacy and bodily integrity."154 The Court held that the proposed surgical procedure to remove a bullet from the suspect's collar bone would amount to a "severe" intrusion on the suspect's "privacy interests."185

Some might dismiss Winston's relevance for EVS based on the difference between the physical intrusion of one's body and the intrusion of one's privacy. Admittedly, the Court thought that the physical intrusion of the proposed surgery was a factor to be considered in balancing private interests. But the Court did not limit its holding to physical integrity cases. Rather the Court used broad language: "When the State seeks to intrude upon an area in which our society recognizes a significantly heightened privacy interest, a more substantial justification is required to make the search 'rea-

\footnotetext{
154 Winston, 470 US at 761 . The Court recognized that another consideration was the impact of the search on the "safety or health of the individual," but found it difficult to assess how risky it would be for the suspect to have a bullet removed from his collarbone. Id at 761, 766. It appears that the Court decided the case on privacy grounds, not on the grounds that the search would be physically harmful to the suspect. See id at 767 .

${ }^{18 s}$ Id at 766 .
} 
sonable." "158 Thus, Winston's definition of unreasonableness can apply equally well to EVS as it does to surgical procedures.

Arguably, when the use of EVS constitutes a search, it intrudes on an individual's interests in privacy as much as the compelled surgical procedures contemplated in Winston. Big Brother inspires considerable fear-whether he forces you to submit to surgery or allows your private activities to be viewed by government agents. The privacy interests in one's bedroom may be as powerful as those in one's collarbone. For many people, a government order allowing agents secretly to tape intimate activities would be as shocking as a government order to submit to surgery.

In fact, in some ways EVS might be more offensively intrusive than the procedure in Winston. The surgery in Winston was to be a one-time intrusion, whereas EVS is often used when the government needs to conduct a search over an extended period of time. ${ }^{157}$ Also, EVS is more indiscriminate. The surgical procedure proposed in Winston was narrowly tailored to gather one piece of evidence, and would have provided the government little information about the suspect other than what was medically necessary. EVS, on the other hand, by its very nature gathers details of a person's life, activities, health, and social connections that have little to do with the criminal investigation.

EVS is also likely to create a greater chilling effect on private, innocent acts than would a surgical procedure like the one at issue in Winston. The Fourth Amendment should protect not only people's material possessions and bodily integrity, but also their ability to engage in innocent acts within their private domain. The knowledge that a physical search or a surgical intrusion could occur will certainly affect a person's activity, but in both cases the victim of the search usually will know when the search is occurring. Any chilling effect of the search on innocent activity will not linger for long, and will probably not extend to activities that the person can cease or modify once she knows that the search is occurring. With EVS, however, people do not know they are being searched. To protect themselves, they must modify their behavior much more comprehensively, making the anxiety caused by the fear of EVS qualitatively different from the fear of physical searches. When a person fears EVS might be used, its inhibiting effect begins long before the camera is installed. When a person has been

\footnotetext{
158 Id at 767.

${ }^{187}$ See Torres, 751 F2d at 884 (EVS is "by nature a continuing rather than one-shot invasion").
} 
subjected to EVS, its inhibiting effect lingers long after the camera has been removed.

b) Government interests. Because privacy interests are normally very strong in EVS cases, the countervailing government interests should trump them only rarely. The Court has identified two factors to measure the importance of the government interests in Fourth Amendment cases: the availability of other evidence and the severity of the crime. The Court described the first factor in Winston. In Winston, the state possessed evidence sufficient to support probable cause for the suspect's arrest, and had used this evidence to demonstrate probable cause to believe that the surgery would produce evidence for trial. ${ }^{158}$ The Court suggested that the prosecution could use this arrest evidence to meet its burden of production at trial. ${ }^{159}$ The additional persuasiveness of evidence garnered through the intrusive search would not qualify as a "compelling need" sufficient to justify the proposed surgical intrusion. ${ }^{160}$ The narrow reading of Winston, therefore, is that when evidence sufficient for arrest is available through other means, the government's desire to gather additional evidence for use at trial is not sufficient to trump the individual's interest in his privacy.

The Court identified the second factor, the severity of the suspected crime, in Welsh $v$ Wisconsin. ${ }^{161}$ In Welsh, police officers entered the home of a person they had probable cause to believe had been driving while intoxicated only minutes earlier. They later sought to justify their warrantless entry by the exigent circumstances exception to the warrant requirement, arguing that the evidence of the crime-the suspect's blood-alcohol level-would have disappeared by the time they obtained a warrant. ${ }^{162}$ Applying a balancing test, the Court held that this suspected crime did not justify an intrusion into the suspect's home; even though no other evidence was available on which to make the arrest, the level of intrusion was too great in relation to the severity of the suspected crime. ${ }^{183}$

188470 US at 765.

${ }^{189}$ Id ("The very circumstances relied on in this case to demonstrate probable cause to believe that evidence will be found tend to vitiate the Commonwealth's need to compel respondent to undergo surgery.").

${ }^{160}$ Id at 766.

161466 US 740 (1984).

182 Id at 753.

${ }^{103}$ Id at 753-54. See also Tennessee $v$ Garner, 471 US 1 (1985), in which the Court held that it was an unreasonable seizure when a police officer shot a fleeing suspect who was not 
In summary, while Winston would allow serious intrusions when evidence from other sources would be insufficient to provide probable cause for arrest, Welsh would prohibit such intrusions in connection with minor crimes. Welsh also stands for the proposition that the more intrusive the government action necessary to seize evidence, the more serious the crime must be to justify the intrusion. ${ }^{164}$

Therefore, in nonpublic, nonconsensual situations-where the use of EVS constitutes a search and thereby implicates privacy interests as great as those in Winston-a judge should not allow its use if other evidence provides probable cause for arrest. The government should not be permitted to use EVS simply to gather superfluous evidence for trial, or to make its case more persuasive to the jury. When EVS is necessary to gather evidence to support probable cause for arrest, a judge should allow its use only in investigations of serious crimes. In other words, the government can justify EVS only when they can show a "compelling need," that is, when a serious crime has occurred or is occurring and probable cause for arrest will not exist without the use of EVS. ${ }^{165}$

Based on this reasonableness balancing analysis, Teicher was wrongly decided. At the time of the application for use of the EVS technology, other evidence existed sufficient to arrest Teicher. Physical evidence, audio surveillance evidence, and complaints of actual victims were available, ${ }^{166}$ and should have been sufficient for arrest. Indeed, Teicher was convicted of two counts of sexual abuse, only the first of which was supported by video evidence.

suspected of committing a violent felony and who did not pose an immediate threat to the officer or to others. The officer could have shown necessity-the suspect would have escaped-but the Court held that the level of the intrusion was not justified by the severity of the suspected crime.

${ }^{164}$ Welsh, 466 US at 753 ("[A]n important factor to be considered when determining whether any exigency exists is the gravity of the underlying offense for which the arrest is being made."). Of course, serious crimes do not in and of themselves justify serious intrusions. The other reasonableness and warrant requirements must be met before intrusive searches are permissible.

${ }_{165}$ This compelling need standard is distinct from the least intrusive means standard required by the warrant clause. Within the reasonableness balancing analysis, the compelling necessity standard looks at the evidence already gathered at the time of the application and permits EVS only if that existing evidence is insufficient for arrest. On the other hand, the least intrusive means requirement allows a judge to grant an application for EVS only when there are no less intrusive means of gathering the same evidence. In other words, reasonableness looks to sufficiency, whereas the least intrusive means inquiry looks to methods. Even if the reasonableness standard is met, the least intrusive means requirement and the other particularity requirements must be satisfied as well.

18B $422 \mathrm{NE} 2 \mathrm{~d}$ at 508. 
People $v$ Dezek ${ }^{167}$ provides an example of EVS that was unreasonable because of the low gravity of the offense. In Dezek, the officials installed a video camera in the stalls of a public restroom to gather evidence of homosexual activity. The defendants were charged with gross indecency between males. While the court had numerous grounds on which it could have based an exclusion of the surveillance evidence, ${ }^{168}$ a reasonableness inquiry would have been sufficient. Society's interest in capturing people engaging in such conduct is not particularly substantial. Allowing EVS in investigations of such offenses offends Welsh.

\section{Congressional balancing.}

Courts should look to Congress for additional guidance as to how they should balance the various factors identified by the Supreme Court, and to learn of other factors that the Supreme Court has not yet considered in the surveillance context. In 1968, when Congress enacted Title III to regulate comprehensively government eavesdropping and wiretapping, EVS did not present a great threat to privacy. Consequently, Congress did not consider whether to include EVS within the regulations and limitations of Title III; the act's extensive regulations do not govern EVS. ${ }^{169}$ Nevertheless, courts have recognized the similarities between audio and visual surveillance and have used Title III to define the Berger particularity requirements for EVS. Unfortunately, these courts have gone only half way; they should accept Title III as relevant in defining constitutional reasonableness for EVS as well. ${ }^{170}$

167107 Mich App 78, 308 NW2d 652 (1981).

168 The court indeed held that the warrant requirements had not been met. 308 NW2d at 657 .

169 The best discussion of this proposition appears in Andonian, 735 F Supp at 1471-77. See also Torres, 751 F2d at 880-82.

170 The Foreign Intelligence Surveillance Act of 1978 (FISA), 50 USC §§ 1801-1811 (1988), placed restrictions on the President's use of surveillance relating to national security. FISA explicitly governs EVS, along with a wide range of other surveillance techniques. 50 USC § 1801(f)(4). Because FISA deals only with national security, courts generally do not look to it as a baseline against which to measure the constitutional requirements for EVS in domestic criminal investigations. See, for example, Torres, 751 F2d at 881-82 (FISA deals with "the special menace posed by agents of foreign powers," not "domestic law enforcement"); Andonian, 735 F Supp at 1472-77.

Nevertheless, a discussion of congressional balancing that used FISA as a baseline would not be very different from the one offered in the text, which uses Title III as a baseline. For the most part, the provisions in FISA parallel those in Title III. See Carr, The Law of Electronic Surveillance at $\$ 9$ (cited in note 5). In some ways, including the mechanisms for approval of a surveillance order, FISA is even stricter than Title III. Andonian, 735 F Supp at 1474 . 
The Torres court accepted Title III as a constitutional measure for EVS, ${ }^{171}$ and also recognized that a reasonableness balancing analysis was appropriate in EVS cases. Torres failed, however, to put these two concepts together. The court thought that the only Title III provisions to have constitutional significance were those implementing the Berger particularity requirements. ${ }^{172}$ For Judge Posner, the additional Title III requirements embodied no constitutional standards.

Some of the non-warrant Title III provisions are indeed constitutional in nature, however, in that they embody protections mandated by Berger, as well as the very type of balancing of interests required by the Fourth Amendment reasonableness standard. The reasonableness standard necessarily depends on what society is willing to give up in personal privacy (or law enforcement) in order to increase law enforcement (or personal privacy). Society has struck such a balance in regard to many electronic surveillance issues; Title III is Congress's "careful legislative attempt"173 to define the appropriate balance between law enforcement and personal privacy in the context of non-visual electronic surveillance. Thus, even though the language of Title III does not explicitly govern EVS, the values expressed in Title III ought to do so. In order to meet the constitutional requirement of reasonableness, the standards for EVS must be at least as protective of privacy as the standards Title III establishes for audio surveillance. ${ }^{174}$

${ }^{171}$ See Torres, 751 F2d at 884 ("Title III was Congress's carefully thought out, and constitutionally valid, effort to implement the requirements of the Fourth Amendment with regard to the necessarily unconventional type of warrant that is used to authorize electronic eavesdropping.") (citations omitted).

172 Id at 885 .

173 Id.

${ }^{174}$ This argument assumes that as surveillance technology becomes more powerful the threat to privacy increases faster than does the value to law enforcement. This is what Congress appears to believe. Title III prohibits all state surveillance statutes that would be more intrusive to privacy and allows state statutes that are more protective of privacy. 18 USC § 2516. Moreover, the belief that technological sophistication heralds increasing dangers to privacy relative to its greater value to law enforcement is also implicit in many of the Supreme Court's opinions. See, for example, United States District Court, 407 US at 312 ("[T] he employment by Government of electronic surveillance [is not necessarily] a welcome development-even when employed with restraint and under judicial supervision."); Berger, 388 US at 63 ("Few threats to liberty exist which are greater than that posed by the use of eavesdropping devices."). Therefore, Title III expresses a "ceiling" on privacy intrusion, and the argument in the text is persuasive. Hypothetically, the Supreme Court and Congress could be wrong. Increasingly intrusive surveillance technology such as EVS could further the government's interests in law enforcement more than it jeopardizes the public's right to privacy. In that case, the arguments in the text extending Title III to EVS would be flawed. 
Title III contains several requirements that go beyond the warrant requirements and codify Congress's reasonableness balancing. ${ }^{175}$ First, Title III permits electronic audio surveillance only for investigations of specified crimes. ${ }^{176}$ The indicated federal offenses fall into three general categories: national security offenses, intrinsically serious offenses such as murder and kidnapping, and offenses characteristic of organized crime. ${ }^{177}$ Second, the applications for surveillance warrants must be centralized in each jurisdiction so as to minimize abuses. ${ }^{178}$ Third, officials must give notice to the people subjected to electronic surveillance after the surveillance has ended. ${ }^{179}$ Fourth, the statute mandates extraordinary measures to protect confidentiality and prevent tampering, including the immediate sealing of the tapes. ${ }^{180}$ Fifth, only judges-not magistrates-may approve electronic surveillance applications. ${ }^{181}$ These provisions embody Fourth Amendment protections and should apply to EVS. ${ }^{182}$

The Seventh Circuit's refusal to interpret these Title III nonwarrant requirements as the measure of constitutional reasonableness would not have altered the analysis in Torres, because all of these provisions were apparently satisfied anyway. ${ }^{183}$ But the absence of these requirements would have altered the analysis in at least two other EVS cases. In Cuevas-Sanchez, the Fifth Circuit allowed the EVS evidence, even though the surveillance had not

${ }^{175}$ See Torres, 751 F2d at 890-91 (Cudahy concurring). See generally Carr, The Law of Electronic Surveillance at $\$ 4$ (cited in note 5).

17818 USC \$§ 2516(1), 2516(2).

${ }^{177}$ Carr, The Law of Electronic Surveillance at $\$ 4.2(a)$ (cited in note 5).

${ }^{178} 18$ USC $\$ \S 2516(1)$ (only senior Justice Department officials may apply for EVS warrants for federal investigations); 2516(2) (only senior state prosecutors may apply for EVS in state investigations); 2518(1)(a) (identity of officer applying must be included in application).

17018 USC $\S \S 2518(7), 2518(8)(d)$.

18018 USC $\$ 2518(8)$ (a).

181 18 USC $\S \S 2516(1)$ (applications submitted "to a federal judge"); 2516(2) (applications submitted to a "state court judge"); 2518 (1) (applications submitted "to a judge").

${ }^{182}$ See, for example, Berger, 388 US at 60 , where the Court took note of the absence of procedures to protect the integrity of the audio tapes as one reason why the eavesdropping was unconstitutional. Nevertheless, some provisions of Title III are not constitutionally based (but rather remedial), so one cannot make the argument that they embody Fourth Amendment protections. See 18 USC §§ 2511(1) (creating criminal penalties for officials engaged in warrantless bugging or wiretapping); 2520 (creating a private cause of action for people targeted by unlawful surveillance); 2515, 2518(10)(a) (broadening the exclusionary rule for information gained in violation of the statute). While Congress certainly should extend these provisions to EVS by statute, courts should not adopt these provisions as part of the constitutional standard of reasonableness as argued in the text for other provisions. In any event, none of these three provisions makes a difference in the analysis of the EVS cases cataloged in Section III.

${ }^{183} 751 \mathrm{~F} 2 \mathrm{~d}$ at 884 . 
been authorized by the proper Justice Department official. ${ }^{184}$ In Ianniello, the district court allowed the introduction of the EVS evidence despite the fact that the government had not submitted the tapes to the district court for sealing, as was required for audio tapes. ${ }^{185}$ The court failed to recognize that the absence of similar procedures to protect the integrity of the tapes was indeed a factor the Berger court considered in striking down the New York eavesdropping statute. ${ }^{186}$

If audio surveillance had been subject to abuses like these, a court would have had grounds to suppress the evidence. ${ }^{187}$ But because the courts in Cuevas-Sanchez and Ianniello subjected EVS to lower standards than audio surveillance, the courts admitted the evidence. In failing to recognize the non-warrant Title III requirements as reasonableness requirements, these courts have created an anomaly in the law: EVS technology is subject to lower restrictions than are less intrusive technologies.

To address this anomaly, some judges have suggested that EVS be subject to the stricter requirements of Title III as a matter of statutory interpretation, ${ }^{188}$ or as a matter of legislative enactment. ${ }^{189}$ Even these judges, however, have set their sights too low. Because Title III embodies both warrant and reasonableness requirements for audio surveillance, the courts should subject EVS to standards at least as strict as Title III as a matter of constitutional law.

\section{ConCLUSION}

This Comment applies the Supreme Court's Fourth Amendment jurisprudence to EVS, a type of technology to which the Court has not yet been required to apply search and seizure analysis. In order to obtain a warrant authorizing EVS, the government must meet very strict standards. The government must show that EVS is the least intrusive means of search available, that the acts and identities and locations subject to surveillance are particularly

184 Namely the Attorney General or Assistant Attorney General. 821 F2d at 252.

$185621 \mathrm{~F}$ Supp at 1468.

${ }^{186} 388$ US at 60.

187 The question of whether or not a court would have actually suppressed the evidence is subject to the complexities of the exclusionary rule, which has its own extensive jurisprudence. See generally Kamisar, LaFave, and Israel, Modern Criminal Procedure at 777-845 (cited in note 28); Office of Legal Counsel, Report to the Attorney General on the Search \& Seizure Exclusionary Rule (GPO, 1986).

${ }^{188}$ See, for example, Judge Cudahy's concurrence in Torres, 751 F2d at 886-95.

189 See, for example, Judge Posner's majority opinion in Torres, 751 F2d at 885. 
described, that the risk to innocent people is minimized, and that the duration of the surveillance is as limited as possible. Based on the factors the Court has specified in other contexts in balancing constitutional reasonableness, Fourth Amendment interests require that the government use EVS only in investigations of serious crimes and only to gather evidence for arrest. Because Title III's provisions embody reasonableness requirements as well as warrant requirements, EVS should also be subject to all such provisions. Lower courts generally have failed to correctly apply the Supreme Court's Fourth Amendment analysis to EVS.

Law enforcement officials should use the standards outlined in this Comment to direct their use of EVS. Judges should use these standards to guide them in deciding whether to authorize or uphold EVS warrants. If courts fail to impose the proper constitutional restrictions, they offer individuals only scant protection from advancing technology and investigator discretion. In a world in which Big Brother peeks from behind the TV screen or peers through the fuzzy navel of a teddy bear, the Fourth Amendment must protect the public, for the public cannot protect itself. 
